\title{
Dwarf Bermudagrass Tolerance to Preemergence Herbicides
}

\author{
Patrick E. McCullough ${ }^{1,3}$ \\ Department of Plant Biology and Pathology, Rutgers, The State University \\ of New Jersey, New Brunswick, NJ 08901-8520
}

Ted Whitwell ${ }^{2}$, Lambert B. McCarty ${ }^{2}$, and Haibo Liu'
Department of Horticulture, Clemson University, Clemson, SC 29634-0319

Additional index words. injury, roots, turfgrass

\begin{abstract}
Preemergence herbicides are applied to prevent summer annual weed infestations in turf, but safety to dwarf-type bermudagrass golf greens has not been determined for many of these materials. Field experiments tested 'TifEagle' bermudagrass response to bensulide at $11.2 \mathrm{~kg} \cdot \mathrm{ha}^{-1}$ (a.i.), dithiopyr at $0.56 \mathrm{~kg} \cdot \mathrm{ha}^{-1}$ (a.i.), napropamide at $2.2 \mathrm{~kg} \cdot \mathrm{ha}^{-1}$ (a.i.), oxadiazon at $2.2 \mathrm{~kg} \cdot \mathrm{ha}^{-1}$ (a.i.), oxadiazon plus bensulide at $1.7+6.7 \mathrm{~kg} \cdot \mathrm{ha}^{-1}$ (a.i.), and pendimethalin at $1.7 \mathrm{~kg} \cdot \mathrm{ha}^{-1}$ (a.i.). All herbicides reduced root mass from the nontreated, but only losses incited by oxadiazon plus bensulide were acceptable (less than $20 \%$ ). Dithiopyr, napropamide, and pendimethalin delayed spring greenup in 2003 and 2004, whereas oxadiazon plus bensulide delayed spring greenup in 2004. In greenhouse experiments, 'TifEagle' bermudagrass root mass was reduced $19 \%$ to $37 \%, 30 \%$ to $33 \%, 4 \%$ to $26 \%, 28 \%$ to $37 \%$, and $24 \%$ to $30 \%$ from various rates of bensulide, dithiopyr, napropamide, and pendimethalin, respectively. Oxadiazon and oxadiaxon plus bensulide reduced root mass by only $2 \%$ to $15 \%$ and $15 \%$ to $22 \%$, respectively. In another experiment, oxadiazon plus bensulide at $1.7+6.7 \mathrm{~kg} \cdot \mathrm{ha}^{-1} \mathrm{did}$ not injure shoots or roots of 'Champion', 'FloraDwarf', 'MiniVerde', 'Tifdwarf', or 'TifEagle' bermudagrass. Overall, dwarf-type bermudagrass golf greens do not appear to tolerate mitotic inhibitor preemergence herbicides, whereas oxadiazon or oxadiazon plus bensulide caused minimal injury.
\end{abstract}

Hybrid bermudagrass (Cynodon dactylon $x$ C. transvaalensis Burtt-Davy) is widely used in the warm, humid climatic regions for golf course putting greens. Traditional bermudagrass putting green cultivars such as 'Tifdwarf' and 'Tifgreen' can only tolerate long-term mowing heights $4.8 \mathrm{~mm}$ or greater, which produce inferior playing surfaces compared with creeping bentgrass (Agrostis stolonifera L.) greens (Beard, 1973; Foy, 1991). Dwarf-type bermudagrass cultivars are improved selections that tolerate long-term mowing heights of $3.2 \mathrm{~mm}$ or less and create fine textured golf greens comparable to creeping bentgrass (Hanna and Elsner, 1999; McCarty and Miller, 2002). Finer leaf textures and lower growth habits of dwarftype cultivars are accredited to genetic and morphologic differences from 'Tifdwarf' and 'Tifgreen' bermudagrass cultivars (Burton, 1991; Capo-chichi et al., 2005; Hannah and Elsner, 1999).

Dwarf-type bermudagrass cultivars require intensive management as a result of poor shade tolerances, heavy thatch/mat accumulation, and disease susceptibility (Bunnell et al., 2005; White, 1998; White

\footnotetext{
Received for publication 17 Apr. 2006. Accepted for publication 22 July 2006.

${ }^{1}$ Program Associate.

${ }^{2}$ Professor.

${ }^{3}$ To whom reprint requests should be addressed; e-mail mccullough@aesop.rutgers.edu
}

et al., 2004). These cultivars are also sensitive to herbicides and plant growth regulators used for managing higher-mowed bermudagrass cultivars such as 'Tifway' bermudagrass and creeping bentgrass golf greens (McCullough et al., 2006; Webster et al., 2003). Although dwarf-type bermudagrass cultivars tolerate close mowing, continuous golf green mowing heights of $3.2 \mathrm{~mm}$ may further exacerbate root growth of these lowgrowing grasses (White, 1998). Practices potentially injurious to dwarf-type bermudagrass roots such as preemergence herbicide applications may reduce turf vigor, inhibit recuperation from stress, and increase susceptibility to root pathogens (Beard, 1973; Engel and Ilnicki, 1969).

Preemergence herbicides are applied in the spring before soil temperatures become favorable for summer annual weed establishment (McCarty and Murphy, 1994). There is also potential for these herbicides to inhibit turfgrass root growth. Warm season grasses such as bermudagrass are vulnerable to root growth inhibition during spring root growth regeneration, which coincides with spring preemergence herbicide applications (Engel and Ilnicki, 1969).

Preemergence herbicides present in soil may reduce bermudagrass root growth from initial and residual herbicide activity. Root tip swelling from preemergence herbicides is characteristic of dinitroanilines (DNA), carbamates, and pyridines commonly used to control summer annual weeds (Vaughn and
Lehnen, 1991). DNA herbicides, like pendimethalin, and pyridimine herbicides such as dithiopyr prevent spindle formation during mitosis by binding to tubuilin proteins necessary for polymerization into microtubules (Ross and Lembi, 1999). Pendimethalin effectively controls summer annual weeds but has shown to cause root growth abnormalities, including enlarged epidermal and cortical cells in 'Tifgreen' bermudagrass (Dernoeden et al., 1984; Finney, 1991). Dithiopyr applied $30 \mathrm{~d}$ after sod installation at 0.84 and $2.5 \mathrm{~kg} \cdot \mathrm{ha}^{-1}$ (a.i.) reduced 'Tifway II' bermudagrass rooting by $59 \%$ and $70 \% 60 \mathrm{~d}$ after treatment (Ferrell et al., 2003). Fall applications of dithiopyr at $0.56 \mathrm{~kg} \cdot \mathrm{ha}^{-1}$ (a.i.) inhibited 'Tifway' bermudagrass establishment up to $25 \%$ compared with the nontreated bermudagrass (Fagerness et al., 2002). Spring applications of dithiopyr have also shown to reduce root mass of 'Penncross' and 'L-93' creeping bentgrass putting greens (Dernoeden et al., 1993; Hart et al., 2004).

Bensulide is a thiocarbamate herbicide that disrupts root cell division, which effectively prevents establishment of annual bluegrass (Poa annua L.) and crabgrass species (Digitaria spp.) in higher-mowed bermudagrass cultivars (Johnson, 1976a; PBI Gordon Corp., 2004; Ross and Lembi, 1999). Bensulide applied at 14 and $28 \mathrm{~kg} \cdot \mathrm{ha}^{-1}$ (a.i.) on dormant 'Tifgreen' bermudagrass caused minimal to no foliar injury during spring transition and summer growth (Callahan, 1976). However, Bingham (1967) reported bensulide at 8.4 and $16.8 \mathrm{~kg} \cdot \mathrm{ha}^{-1}$ (a.i.) reduced root mass of 'Tifgreen' bermudagrass in greenhouse and field experiments. Bensulide also inhibited root growth of 'Belair' zoysiagrass (Fry et al., 1986), 'Merion' Kentucky bluegrass (Poa pratensis) (Engel and Callahan, 1967), and 'L-93' creeping bentgrass (Hart et al., 2004).

Oxadiazon is commonly applied for preemergence control of summer annual weeds in bermudagrass tees, fairways, and roughs (Bayer Environmental Sciences, 1998). Oxadiazon has residual activity of 8 to 15 weeks and inhibits the enzyme protoporphyrinogen oxidase causing loss of chlorophyll and eventually membrane leakage (Rao, 2000). On 'Tifgreen' bermudagrass, oxadiazon gave $100 \%$ control of Digitaria sanguinalis (L.) in 3 consecutive years (Callahan and High, 1990). Single and sequential applications of oxadiazon effectively control Kyllinga squamulata, annual bluegrass, and goosegrass (Eleusine indica L.) in higher-mowed bermudagrass turf (Johnson, 1976a; Bunnell et al., 2001; Toler et al., 2003). Oxadiazon is also used in combination with bensulide for preemergence weed control in bermudagrass turf. Dernoeden et al. (1984) noted oxadiazon at $1.7 \mathrm{~kg} \cdot \mathrm{ha}^{-1}$ (a.i.) with bensulide at 6.7 $\mathrm{kg} \cdot \mathrm{ha}^{-1}$ (a.i.) effectively controlled goosegrass and crabgrass (Digitaria spp.). Johnson (1980) noted the registered rate of oxadiazon, $4.5 \mathrm{~kg} \cdot \mathrm{ha}^{-1}$ (a.i.), did not reduce rooting of 'Tifgreen', 'Tifdwarf', or 'Tifway' bermudagrass in field experiments. 
Napropamide is an amide herbicide that is registered for use on warm-season grasses, including bermudagrass (Gowan Company, 2004). Napropamide effectively controls summer annual weeds when applied at 2.2 and $4.4 \mathrm{~kg} \cdot \mathrm{ha}^{-1}$ (a.i.) (Dernoeden et al., 1984). However, Johnson (1980) noted napropamide at 3.4 and $10.2 \mathrm{~kg} \cdot \mathrm{ha}^{-1}$ reduced root mass of 'Tifgreen', 'Tifdwarf', and 'Tifway' bermudagrass.

Previous investigations have documented weed control and tolerance of traditional bermudagrass putting green cultivars to preemergence herbicides. However, dwarf-type bermudagrass is genetically and morphologically distinct from these varieties, which may increase sensitivity to herbicide applications (Burton, 1991; Capo-chichi et al., 2005; Hannah and Elsner, 1999). Because these cultivars are being widely planted for southern golf greens, research is warranted regarding safety to preemergence herbicide applications. The objective of these experiments was to investigate tolerance of dwarf bermudagrass golf greens to preemergence herbicide applications.

\section{Materials and Methods}

Field experiments. Field experiments were conducted from March to Aug. 2003 and 2004 on a 'TifEagle' bermudagrass green established in July 2002 at the Turfgrass Service Center, Clemson, S.C., built to U.S. Golf Association specifications (U.S. Golf Assoc. Green Section Staff, 1993). Soil texture was $2 \%$ very coarse sand $(1 \mathrm{~mm}$ or greater $), 9 \%$ coarse sand $(0.5$ to $1.0 \mathrm{~mm})$, $31 \%$ medium sand ( 0.25 to $0.5 \mathrm{~mm}$ ), $36 \%$ fine sand ( 0.1 to $0.25 \mathrm{~mm}), 20 \%$ very fine sand (less than $0.1 \mathrm{~mm}$ ), and $2 \%$ organic matter with a $5.9 \mathrm{pH}$. The experimental design was a randomized complete block with four replications of $1.2-\mathrm{m}^{2}$ plots. Plots in 2004 were adjacent to those used in 2003.

Turf was maintained at $3.2-\mathrm{mm}$ mowing height and irrigated as needed to prevent plant wilt. Potash was applied at $48 \mathrm{~kg} \cdot \mathrm{ha}^{-1}$ (K) in late Apr. 2003 to help correct initial K deficiencies. Bermudagrass received weekly fertilizations of a greens-grade granular fertilizer $(18 \mathrm{~N}-1 \mathrm{P}-15 \mathrm{~K})$ at $12 \mathrm{~kg} \cdot \mathrm{ha}^{-1}(\mathrm{~N})$ beginning the first week of May until midAugust in both years.

Herbicides were applied 3 Mar. 2003 and 1 Mar. 2004. Herbicides tested included bensulide, dithiopyr, napropamide, oxadiazon, oxadiazon plus bensulide, and pendimethalin. Because no preemergence herbicides are currently registered for 'TifEagle' bermudagrass, rates for 'Tifgreen' bermudagrass and creeping bentgrass putting greens were applied (Table 1). Sprayable formulations were applied with a single-nozzle $\mathrm{CO}_{2}$ sprayer delivering $700 \mathrm{~L} \cdot \mathrm{ha}^{-1}$. Granular formulations were applied with a shaker can. Turf was irrigated to $\approx 6$-mm depth immediately after herbicide applications. 'TifEagle' bermudagrass was completely dormant when herbicides were applied in both years. Spring greenup was rated every 3 weeks after appli-

Table 1. Herbicides and rates applied to TifEagle bermudagrass in field and greenhouse experiments.

\begin{tabular}{|c|c|}
\hline Herbicide $^{z}$ & Rate kg.ha ${ }^{-1}$ (a.i.) \\
\hline \multicolumn{2}{|c|}{ Field experiment } \\
\hline Bensulide & 11.2 \\
\hline Dithiopyr & 0.56 \\
\hline Napropamide & 2.2 \\
\hline Oxadiazon & 2.2 \\
\hline Oxadiazon + bensulide & $1.7+6.7$ \\
\hline Pendimethalin & 1.7 \\
\hline \multicolumn{2}{|c|}{ Greenhouse experiments } \\
\hline Bensulide & $0,5.6,11.2,16.8$ \\
\hline Dithiopyr & $0,0.14,0.28,0.56$ \\
\hline Napromamide & $0,1.1,2.2,3.3,4.4$ \\
\hline Oxadiazon & $0,1.1,2.2,3.3$ \\
\hline Oxadiazon + bensulide & $0,0.9+3.4,1.7+6.7,3.4+13.4$ \\
\hline Pendimethalin & $0,0.6,1.1,1.7,2.2$ \\
\hline
\end{tabular}

${ }^{2}$ Herbicide products applied were: Bensumec 4LF (bensulide), PBI Gordon Corp., Kansas City, Mo.; Dimension 1EC (dithiopyr), Dow AgroSciences LLC, Indianapolis, Ind.; Devrinol 50WP (napropamide) Gowan Company, Trenton, N.J.; Ronstar 2G and 50WP (oxadiazon), Bayer Environmental Sciences, Montvale, N.J.; Scott's Crab and Goose 6.56G (oxadiazon + bensulide), Marysville, Ohio; PreM 60WP (pendimethalin), Strongesville, Ohio.

cations on a percent scale with $0 \%=$ dormant turf and $100 \%=$ complete green turf.

Two root samples were harvested per plot with a $5-\mathrm{cm}$ diameter and $30-\mathrm{cm}$ depth sampler on seven dates and backfilled with sand. Sampling dates were 21 Mar., 11 Apr., 5 May, 26 May, 16 June, 30 June, 18 Aug. in 2003 and 22 Mar., 12 Apr., 4 May, 24 May, 14 June, 5 July, and 11 Aug. in 2004. Roots were thoroughly washed to remove soil and organic matter over sieve screens that prevented loss of root fragments. Samples were oven dried at $80^{\circ} \mathrm{C}$ for $72 \mathrm{~h}$. The two samples per plot were pooled and data were subjected to analysis of variance with SAS General Linear Model procedure (SAS Institute, 1999). Mean separations were made with Fisher's protected least significant difference (LSD) test at $\alpha=0.05$.

Greenhouse Expt. 1. Greenhouse experiments were performed at the Clemson University Greenhouse Research Complex, Clemson, S.C., from Jan. to Aug. 2003. Greenhouse day/night temperatures ranged from $26 / 20{ }^{\circ} \mathrm{C}$. Sod was collected from the 'TifEagle' bermudagrass green at the Turfgrass Service Center, Clemson, S.C. Bermudagrass plugs were placed in pots with $15-\mathrm{cm}$ diameters and 12-cm depth with an 85/15 (v/v) sand and peatmoss medium. A 9-18-17 starting fertilizer $\left(\mathrm{N}: \mathrm{P}_{2} \mathrm{O}_{5}: \mathrm{K}_{2} \mathrm{O}\right.$; Scott's, Marysville, Ohio) was mixed into the soil at $48 \mathrm{~kg} \cdot \mathrm{ha}^{-1}(\mathrm{~N})$. The fertilizer also contained $\mathrm{Ca}$, $\mathrm{Mg}$, and $\mathrm{S}$ at $4 \%, 2 \%$, and $7 \%$, respectively.

'TifEagle' bermudagrass was allowed to resume active growth for $\approx 2$ weeks before treatments. Turf was irrigated and mowed with grass sheers (Black and Decker, Towson, Md.) at $\approx 4 \mathrm{~mm} 5 \mathrm{~d} \cdot$ week $^{-1}$. Weekly nitrogen inputs were applied with ammonium nitrate at $12 \mathrm{~kg} \cdot \mathrm{ha}^{-1}(\mathrm{~N})$.

Each herbicide tested in field experiments was applied in separate experiments at four rates based on application rates for creeping bentgrass greens and 'Tifgreen' bermudagrass (Table 1). Herbicide applications were made at $720 \mathrm{~L} \cdot \mathrm{ha}^{-1}$ with a Devries (Hollandale, Minn.) Manufacturing sprayer model SB6094. Experimental designs were randomized complete blocks with four replications and experiments were repeated for each herbicide. Blocks were rotated biweekly and experimental units rerandomized within.

Roots were harvested from entire pots 6 weeks after treatments and washed thoroughly over sieve screens that prevented loss of root fragments. Roots were then ovendried at $80^{\circ} \mathrm{C}$ for $48 \mathrm{~h}$ and weighed. Before data analysis, root growth reductions from nontreated pots were calculated by the following equation: percent root mass reductions $=100 \times\left[\left(\operatorname{mass}_{0}-\operatorname{mass}_{\mathrm{x}}\right) / \operatorname{mass}_{0}\right]$, where mass $_{\mathrm{X}}$ equaled root mass of treated turf and mass $_{0}$ equaled root mass of nontreated turf. Data were subjected to analysis of variance and regression analysis with SAS General Linear Model procedure and SAS Proc Reg (SAS Institute, 1999). From regression analysis, herbicide rate was calculated that reduced root mass $20 \%$ from nontreated turf.

Greenhouse Expt. 2. Preliminary results from field experiments suggested 'TifEagle' bermudagrass tolerated oxadiazon plus bensulide and thus, greenhouse experiments investigated responses of five dwarf-type bermudagrass cultivars to the herbicide. Two experiments were conducted at the Clemson University Greenhouse Research Complex, Clemson, S.C., from Oct. to Nov. 2003 (Study 1) and Jan. to Feb. 2004 (Study 2 ). Greenhouse day/night temperatures were set for $\approx 26 / 20{ }^{\circ} \mathrm{C}$. As a result of reduced lighting during winter months, supplemental lighting was added for $\approx 3 \mathrm{~h} / \mathrm{d}$ at 50 $\mu \mathrm{mol} \cdot \mathrm{m}^{2} \cdot \mathrm{s}^{-1}$. The experimental design was a randomized complete block with four replications of 10 containers per block. To help reduce light variability during winter months, blocks were rotated biweekly and experimental units rerandomized within. 'TifEagle' and 'Champion' bermudagrass sod was collected from putting greens at the Turf Service Center, Clemson, S.C., established in July 2002 and 2003, respectively. 'Tifdwarf' and 'MiniVerde' bermudagrass sod was obtained from American Turf in Duluth, Ga. 'FloraDwarf' bermudagrass sod was obtained from the University of Florida, Gainesville. 
Sod was established in $10-\mathrm{cm}$ pots in the greenhouse for $\approx 4$ weeks. Turf was then removed from pots, washed free of soil, and roots were cut to $\approx 2.5 \mathrm{~cm}$ from the thatch layer. Sod plugs were then transplanted to PVC containers. Containers had $40-\mathrm{cm}$ depths with $177-\mathrm{cm}^{2}$ surface areas and built to United States Golf Association specification (U.S. Golf Assoc. Green Section Staff, 1993) with an 85 sand : 15 peatmoss root zone mix (by volume). Sand texture was $4 \%$ coarse sand ( 0.5 to $1.0 \mathrm{~mm}), 30 \%$ medium sand ( 0.25 to $0.5 \mathrm{~mm}), 48 \%$ fine sand ( 0.1 to $0.25 \mathrm{~mm}$ ), and $16 \%$ very fine sand (less than $0.1 \mathrm{~mm})$. Starting fertilizer, 9-18-17, was mixed into the soil at $48 \mathrm{~kg} \cdot \mathrm{ha}^{-1}(\mathrm{~N})$.

After transplanting sod to containers, turf was allowed to resume active growth before treatments. Oxadiazon plus bensulide $(6.6 \mathrm{G}$, $1.3 \%$ oxadiazon $+5.3 \%$ bensulide) was applied from a prepackaged combination at $1.7+6.7 \mathrm{~kg} \cdot \mathrm{ha}^{-1}\left(130 \mathrm{~kg} \cdot \mathrm{ha}^{-1}\right.$ of product $)$ to initiate the 8 -week studies. Turf was irrigated and mowed with automatic grass sheers (Black and Decker, Towson, Md.) at $4 \mathrm{~mm}$ $5 \mathrm{~d} \cdot$ week $^{-1}$. Ammonium nitrate solution was applied weekly at $12 \mathrm{~kg} \cdot \mathrm{ha}^{-1}(\mathrm{~N})$.

Turf quality was rated weekly on a 1 to 9 scale with 9 being dark green turf and 1 completely dormant turf. Ratings below 7 were considered unacceptable. Turf injury was evaluated on a percent scale basis, in which $0 \%=$ no injury and $100 \%=$ completely dead turf. Clippings were harvested 4 and 8 weeks after treatment (WAT). Roots were collected from entire containers at the 0 to $15 \mathrm{~cm}$ and 15 to $30-\mathrm{cm}$ depths 8 WAT and were cut $\approx 2.5 \mathrm{~cm}$ below the thatch layer. Root length was determined to the nearest $1.3 \mathrm{~cm}$ by measuring the distance from where roots were no longer present in the soil profile to the top of the container. After harvestings, clippings and roots were oven-dried at $80{ }^{\circ} \mathrm{C}$ for $48 \mathrm{~h}$ and then weighed. Data were subjected to an analysis of variance with SAS General Linear Model procedure. Mean separations were based on Fisher's protected LSD test at $\alpha=0.05$.

\section{Results and Discussion}

Year-by-treatment and year-by-week interactions were detected for spring greenup and thus, results are presented for each evaluation date by year. For nontreated turf, initial spring greenup had occurred by 21 Mar. 2003 and $100 \%$ full greenup was noted by 23 June 2003 (Table 2). Bensulide and oxadiazon + bensulide treatments had similar spring greenup as nontreated turf in 2003, whereas oxadiazon only had greenup reduced $11 \%$ on one date. 'TifEagle' bermudagrass treated with dithiopyr had $14 \%$ to $45 \%$ reduced green color from nontreated turf on 11 Apr., 5 May, and 26 May 2003. Turf treated with napropamide had $26 \%$ to $46 \%$ less green color from nontreated turf on 24 Mar. and 11 Apr. 2003. Bermudagrass treated with pendimethalin had $14 \%$ to $26 \%$ less green color than nontreated turf on 11 Apr., 5 May, and 26 May 2003. Turf treated with
Table 2. Effect of preemergence herbicides on TifEagle bermudagrass spring greenup in field experiments, Clemson, S.C. ${ }^{\mathrm{z}}$

\begin{tabular}{lcccccr}
\hline & & \multicolumn{5}{c}{ Spring greenup (WAT (W) $^{\mathrm{y}}(\%)$} \\
\cline { 3 - 7 } Herbicide $^{\mathrm{x}}$ & Rate kg.ha $^{-1}$ (a.i.) & 3 & 6 & 9 & 12 & 15 \\
\hline & & 2003 & & & & \\
Nontreated & - & $35 \mathrm{a}$ & $70 \mathrm{a}$ & $75 \mathrm{a}$ & $94 \mathrm{a}$ & 100 \\
Bensulide & 11.2 & $38 \mathrm{a}$ & $73 \mathrm{a}$ & $74 \mathrm{a}$ & $88 \mathrm{ab}$ & 100 \\
Dithiopyr & 0.56 & $30 \mathrm{a}$ & $43 \mathrm{c}$ & $40 \mathrm{c}$ & $63 \mathrm{c}$ & 98 \\
Napromamide & 2.2 & $20 \mathrm{~b}$ & $59 \mathrm{~b}$ & $76 \mathrm{a}$ & $89 \mathrm{ab}$ & 100 \\
Oxadiazon & 2.2 & $33 \mathrm{a}$ & $69 \mathrm{a}$ & $71 \mathrm{a}$ & $83 \mathrm{~b}$ & 100 \\
Oxadiazon + bensulide & $1.7+6.7$ & $40 \mathrm{a}$ & $70 \mathrm{a}$ & $74 \mathrm{a}$ & $94 \mathrm{a}$ & 100 \\
Pendimethalin & 1.7 & $43 \mathrm{a}$ & $58 \mathrm{~b}$ & $58 \mathrm{~b}$ & $70 \mathrm{c}$ & 100 \\
& & 2004 & & & & \\
Nontreated & - & 0 & $9 \mathrm{ab}$ & $90 \mathrm{a}$ & 100 & 100 \\
Bensulide & 11.2 & 0 & $13 \mathrm{a}$ & $98 \mathrm{a}$ & 100 & 100 \\
Dithiopyr & 0.56 & 0 & $5 \mathrm{bc}$ & $56 \mathrm{c}$ & 100 & 100 \\
Napromamide & 2.2 & 0 & $1 \mathrm{c}$ & $74 \mathrm{~b}$ & 100 & 100 \\
Oxadiazon & 2.2 & 0 & $5 \mathrm{bc}$ & $91 \mathrm{a}$ & 100 & 100 \\
Oxadiazon + bensulide & $1.7+6.7$ & 0 & $5 \mathrm{bc}$ & $75 \mathrm{~b}$ & 100 & 100 \\
Pendimethalin & 1.7 & 0 & $1 \mathrm{c}$ & $71 \mathrm{~b}$ & 100 & 100 \\
\hline
\end{tabular}

${ }^{2}$ Different letters indicate a significant difference at the $0.05 P$ level according to Fisher's protected least significant difference test.

${ }^{\mathrm{y}} \mathrm{WAT}=$ weeks after treatment. All plots were dormant the day of herbicide application. Herbicides were applied 3 Mar. 2003 and 1 Mar. 2004. 2003: $3 \mathrm{WAT}=21$ Mar., $6 \mathrm{WAT}=11 \mathrm{Apr}$., $9 \mathrm{WAT}=5 \mathrm{May}$, $12 \mathrm{WAT}=26$ May, $15 \mathrm{WAT}=16$ June. 2004: $3 \mathrm{WAT}=22$ Mar., $6 \mathrm{WAT}=12$ Apr., $9 \mathrm{WAT}=4$ May, $12 \mathrm{WAT}=24$ May.

${ }^{x}$ Herbicide products applied were: Dimension 1EC (dithiopyr), Dow AgroSciences LLC, Indianapolis, Ind.; Devrinol 50WP (napropamide) Gowan Company, Trenton, N.J.; Scott's Crab and Goose 6.56G (oxadiazon + bensulide), Marysville, Ohio; PreM 60WP (pendimethalin), Strongesville, Ohio.

herbicides had complete green color on 16 June 2003.

In 2004, initial bermudagrass greenup was observed on 12 Apr. (Table 2). By 4 and 24 May, nontreated 'TifEagle' bermudagrass had $90 \%$ and $100 \%$ green color, respectively. Bensulide and oxadiazon did not reduce spring greenup from nontreated turf in 2004. Reduced green color was detected on 12 Apr. 2004 for 'TifEagle' bermudagrass treated with napropamide and pendimethalin, but nontreated turf only had $9 \%$ green color. On 4 May 2004, turf treated with dithiopyr, napropoamide, oxadiazon plus bensulide, and pendimethalin had $38 \%, 18 \%, 17 \%$, and $21 \%$ less green color than nontreated turf, respectively. 'TifEagle' bermudagrass treated with herbicides had complete green coverage by 24 May 2004.

Sampling date-by-treatment interaction was not detected for root mass and thus results were pooled and presented by treatment (Table 3). All herbicides significantly reduced root mass compared with the nontreated; however, root loss with oxadiazon plus bensulide was considered acceptable (less than 20\%). Bermudagrass root loss when treated with bensulide, dithiopyr, napropamide, oxadiazon, and pendimethalin ranged from $22 \%$ to $39 \%$ from nontreated. However, turf treated with oxadiazon alone had similar root mass as oxadiazon plus bensulide treatments.

From greenhouse experiments, 'TifEagle' bermudagrass root mass was reduced from nontreated by $19 \%$ to $37 \%, 30 \%$ to $33 \%, 4 \%$ to $26 \%$, and $28 \%$ to $37 \%$ from bensulide, dithiopyr, napropamide, and pendimethalin, respectively (Fig. 1). Differences were not detected among formulations of oxadiazon (wettable powder versus granular), so results were pooled over formulations. Oxadiazon- treated turf had root mass reductions ranging $2 \%$ to $15 \%$ from nontreated turf, whereas oxadiazon plus bensulide reduced root mass $15 \%$ to $22 \%$. From regression analysis, $20 \%$ root mass reductions occurred at $6.1,0.09$, 1.83, $2+7.8$, and $0.86 \mathrm{~kg} \cdot \mathrm{ha}^{-1}$ (a.i.) from bensulide, dithiopyr, napropamide, oxadiazon plus bensulide, and pendimethalin, respectively (Table 4). 'TifEagle' bermudagrass root mass reductions from oxadiazon had no statistical relationship with rates but the $2 \times$ rate $\left(4.4 \mathrm{~kg} \cdot \mathrm{ha}^{-1}\right)$ had $\approx 20 \%$ reductions from that nontreated.

Regression analysis from data collected in the greenhouse support observations in field experiments in which low rates of mitotic inhibitors for higher-mowed bermudagrass resulted in greater than $20 \%$ root mass reductions from nontreated turf. Predicted rate of napropamide to reduce root mass $20 \%$ was $17 \%$ lower than rates registered for weed control in warm-season turf. Napropamide reduced 'TifEagle' bermudagrass root growth and delayed spring greenup in both years. Johnson and Burns (1985) noted napropamide reduced early spring quality of common bermudagrass maintained at 25 to 40-mm mowing height. Johnson (1980) noted napropamide at 3.4 and $10.2 \mathrm{~kg} \cdot \mathrm{ha}^{-1}$ reduced root mass of 'Tifgreen', 'Tifdwarf', and 'Tifway' bermudagrass cultivars. Johnson also noted napropamide applications reduced root growth of zoysiagrass.

Bensulide and pendimethalin applied to 'TifEagle' bermudagrass in the greenhouse reduced root mass $20 \%$ at rates $45 \%$ to $50 \%$ less than the lowest rates registered for weed control. Pendimethalin is widely used on bermudagrass fairways, roughs, and lawns for summer annual weed control (Lesco, Inc., 2001) but appears injurious when applied to dwarf-type bermudagrass putting greens. 
Table 3. Dry root mass as affected by six preemergence herbicides applied in field experiments, Clemson, S.C.

\begin{tabular}{lcc}
\hline Herbicide $^{\mathrm{y}}$ & ${\text { Rate } \mathrm{kg} \cdot \mathrm{ha}^{-1}(\text { a.i. })}$ & Dry root mass $^{\mathrm{x}}\left(\mathrm{g} \cdot \mathrm{m}^{2}\right)$ \\
\hline Nontreated & - & $32 \mathrm{a}$ \\
Bensulide & 11.2 & $21 \mathrm{~cd}$ \\
Dithiopyr & 0.6 & $20 \mathrm{~d}$ \\
Napromamide & 2.2 & $23 \mathrm{~cd}$ \\
Oxadiazon & 2.2 & $25 \mathrm{bc}$ \\
Oxadiazon + bensulide & $1.7+6.7$ & $27 \mathrm{~b}$ \\
Pendimethalin & 1.7 & $23 \mathrm{~cd}$ \\
\hline
\end{tabular}

${ }^{\mathrm{z}}$ Different letters indicate a significant difference at the $0.05 P$ level according to Fisher's protected least significant difference test.

${ }^{y}$ Herbicides were applied 3 Mar. 2003 and 1 Mar. 2004. Herbicide products applied were: Bensumec 4LF (bensulide), PBI Gordon Corp., Kansas City, Mo.; Dimension 1EC (dithiopyr), Dow AgroSciences LLC, Indianapolis, Ind.; Devrinol 50WP (napropamide) Gowan Company, Trenton, N.J.; Ronstar 2G (oxadiazon), Bayer Environmental Sciences, Montvale, N.J.; Scott's Crab and Goose 6.56G (oxadiazon + bensulide), Marysville, Ohio; PreM 60WP (pendimethalin), Strongesville, Ohio.

${ }^{x}$ Root sampling dates; 2003: 21 Mar., 11 Apr., 5 May, 26 May, 16 June, 30 June, 18 Aug. 2004: 22 Mar, 12 Apr., 4 May, 24 May, 14 June, 5 July, 11 Aug. Two samples, $20 \mathrm{~cm}^{2} \times 30 \mathrm{~cm}$ in size, were harvested per plot on each date.
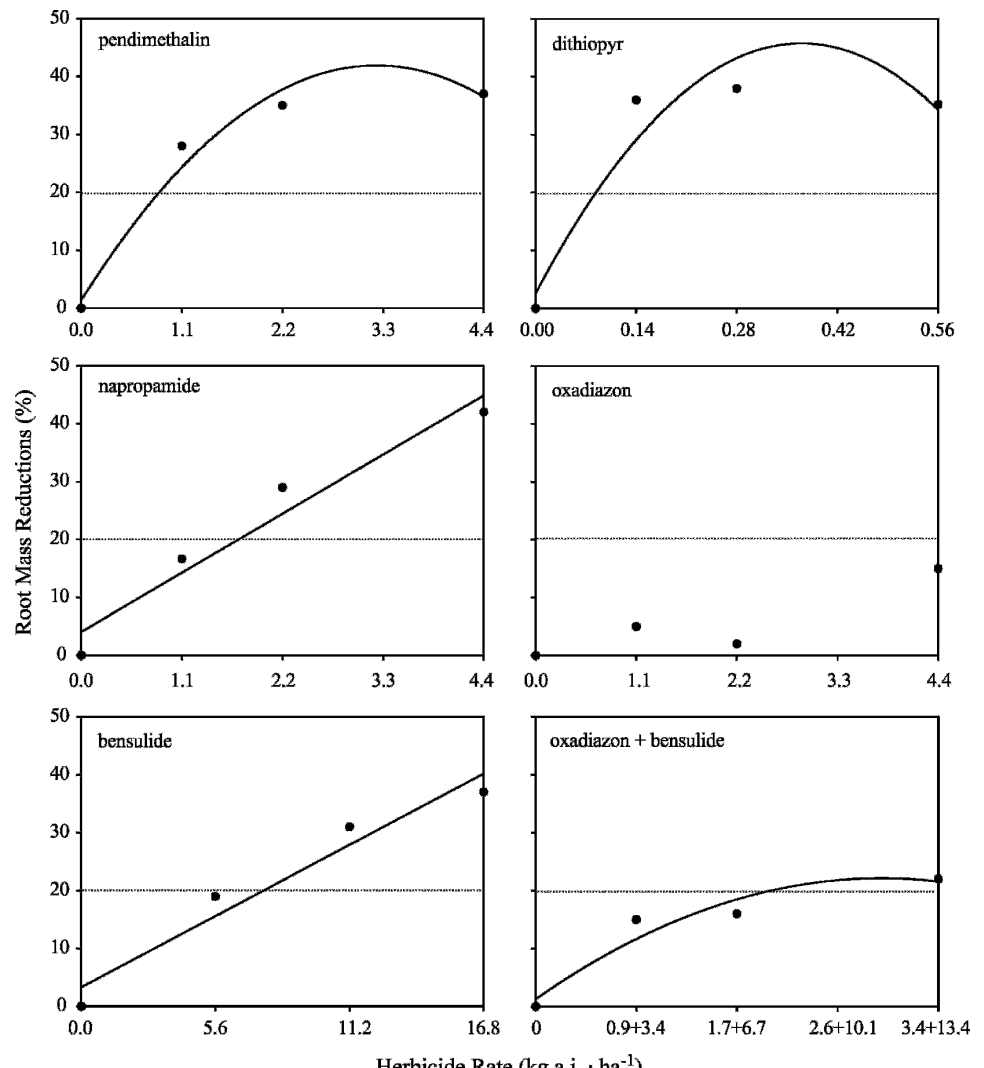

Fig. 1. Root mass reductions of 'TifEagle' bermudagrass after preemergence herbicide treatments in two combined greenhouse experiments, Clemson, S.C.

Table 4. Predicted root mass reductions from regression analysis for TifEagle bermudagrass treated with preemergence herbicides in two combined greenhouse experiments, Clemson, S.C.

\begin{tabular}{|c|c|c|c|}
\hline Herbicide $^{z}$ & $\begin{array}{l}\text { Root mass reductions } \\
(20 \% \text { of untreated }) \\
\mathrm{kg} \cdot \mathrm{ha}^{-1} \text { (a.i.) }\end{array}$ & $\mathrm{r}^{2}$ & equation \\
\hline Benuslide & 6.1 & 0.51 & $\mathrm{y}=0.08+3.93 \mathrm{x}-0.11 \mathrm{x}^{2}$ \\
\hline Dithiopyr & 0.09 & 0.32 & $y=2.34+236.26 x-319.97 x^{2}$ \\
\hline Napropamide & 1.83 & 0.58 & $\mathrm{y}=1.97+9.87 \mathrm{x}$ \\
\hline Oxadiazon & NS & NS & \\
\hline Oxadiazon + bensulide & $(2+7.8)$ & 0.10 & $y=1.59+24.61-7.52 x^{2}$ \\
\hline Pendimethalin & 0.86 & 0.28 & $y=1.44+24.72 x-3.80 x^{2}$ \\
\hline \multicolumn{4}{|c|}{$\begin{array}{l}\text { ¿Herbicide products applied were: Bensumec 4LF (bensulide), PBI Gordon Corp., Kansas City, Mo.; } \\
\text { Dimension 1EC (dithiopyr), Dow AgroSciences LLC, Indianapolis, Ind.; Devrinol 50WP (napropamide) } \\
\text { Gowan Company, Trenton, N.J.; Ronstar 2G and 50WP (oxadiazon), Bayer Environmental Sciences, } \\
\text { Montvale, N.J.; Scott's Crab and Goose 6.56G (oxadiazon + bensulide), Marysville, Ohio; PreM 60WP } \\
\text { (pendimethalin), Strongesville, Ohio. } \\
\text { NS Nonsignificant. }\end{array}$} \\
\hline
\end{tabular}

Root growth inhibition and delayed spring greenup of 'TifEagle' bermudagrass suggest pendimethalin has potential to injure dwarftype bermudagrass greens at rates registered for weed control.

'TifEagle' bermudagrass root growth was inhibited from bensulide and dithiopyr in field and greenhouse experiments. Bensulide at $11.2 \mathrm{~kg} \cdot \mathrm{ha}^{-1}$ did not delay spring greenup but did reduce root growth of 'TifEagle' bermudagrass. Callahan (1976) noted bensulide applied at 14 and $28 \mathrm{~kg} \cdot \mathrm{ha}^{-1}$ did not injure shoots of 'Tifgreen' bermudagrass during spring and summer growth, but Bingham (1967) noted bensulide at 8.4 and 16.8 $\mathrm{kg} \cdot \mathrm{ha}^{-1}$ reduced 'Tifgreen' root mass. Bensulide can also inhibit root growth of zoysiagrass (Fry et al., 1986), Kentucky bluegrass (Engel and Callahan, 1967), and creeping bentgrass (Dernoeden et al., 1993; Hart et al., 2004). Although bensulide is currently labeled for bermudagrass and bentgrass putting greens (PBI Gordon Corp., 2004), results suggest bensulide should not be used on 'TifEagle' bermudagrass at rates registered for weed control. Dithiopyr is registered for bermudagrass at 0.28 to $0.56 \mathrm{~kg} \cdot \mathrm{ha}^{-1}$ but is not registered for use on 'Tifgreen' bermudagrass (Dow AgroSciences LLC, 2003). Regression analysis of 'TifEagle' greenhouse experiments indicated that $20 \%$ root mass reductions occurred from dithiopyr at a rate $68 \%$ less than the lowest labeled rate.

Results with oxadiazon applied to 'TifEagle' bermudagrass are consistent with previous research by Callahan and High (1990) who found minimal to no foliar injury during spring transition on 'Tifgreen' bermudagrass. Johnson (1976b, 1979) noted spring applications of oxadiazon at 3.4 and $4.5 \mathrm{~kg} \cdot \mathrm{ha}^{-1} \mathrm{did}$ not affect quality or density of 'Tifway', 'Tifgreen', 'Tifdwarf', 'Ormond', or 'Floraturf' bermudagrass when maintained at 20 to $40-\mathrm{mm}$ mowing heights, but injury was reported from fall applications. Applications of oxadiazon in May were reported not to injure 'Tifway', 'Tifgreen', or 'Tifdwarf' bermudagrass, whereas applications in early spring, summer, or fall reduced quality and density from that nontreated (Johnson, 1985).

Oxadiazon and oxadiazon plus bensulide reduced 'TifEagle' bermudagrass root growth in field experiments, but reductions were generally acceptable as noted in greenhouse experiments. Johnson $(1980,1985)$ noted oxadiazon at $4.5 \mathrm{~kg} \cdot \mathrm{ha}^{-1}$ did not reduce rooting of 'Tifgreen', 'Tifdwarf', and 'Tifway' bermudagrass cultivars. In Johnson's experiments, 'Tifgreen' and 'Tifdwarf' bermudagrass cultivars were mowed $2 \mathrm{~d} \cdot$ week $^{-1}$ at $20 \mathrm{~mm}$, whereas 'TifEagle' bermudagrass in this field experiment was mowed daily at $3.2 \mathrm{~mm}$. Thus, greater sensitivity of 'TifEagle' bermudagrass to preemergence herbicides may be a function of closer mowing heights attributable to morphologic and genetic variations from traditional bermudagrass cultivars.

In experiments comparing five dwarf bermudagrass cultivars, oxadiazon plus 
Table 5. Clipping yield, root mass, and root length of five dwarf bermudagrass cultivars 8 weeks after treatments with oxadiazon plus bensulide in two combined greenhouse experiments. ${ }^{2}$

\begin{tabular}{|c|c|c|c|c|c|c|}
\hline \multirow[b]{2}{*}{ Cultivar } & \multicolumn{2}{|c|}{ Clipping yield $\left(\mathrm{g} \cdot \mathrm{m}^{2}\right)$} & \multicolumn{3}{|c|}{ Dry root mass (soil depth) $\left(\mathrm{g} \cdot \mathrm{m}^{2}\right)$} & \multirow{2}{*}{$\begin{array}{l}\text { Root length } \\
\quad(\mathrm{cm})\end{array}$} \\
\hline & Nontreated & Treated & $0-15 \mathrm{~cm}$ & $15-30 \mathrm{~cm}$ & Total & \\
\hline Champion & $2.0 \mathrm{~b}$ & $1.9 \mathrm{a}$ & $9.9 \mathrm{c}$ & $2.5 \mathrm{c}$ & $12.4 \mathrm{c}$ & $25 \mathrm{a}$ \\
\hline FloraDwarf & $1.2 \mathrm{c}$ & $0.9 \mathrm{~b}^{\mathrm{y}}$ & $13.4 \mathrm{~b}$ & $3.8 \mathrm{bc}$ & $17.2 \mathrm{~b}$ & $25 \mathrm{a}$ \\
\hline MiniVerde & $1.4 \mathrm{c}$ & $1.3 \mathrm{~b}$ & $16.2 \mathrm{a}$ & $5.5 \mathrm{ab}$ & $21.7 \mathrm{a}$ & $27 \mathrm{a}$ \\
\hline Tifdwarf & $1.2 \mathrm{c}$ & $1.0 \mathrm{~b}$ & $12.7 \mathrm{bc}$ & $6.0 \mathrm{a}$ & $18.7 \mathrm{ab}$ & $27 \mathrm{a}$ \\
\hline TifEagle & $2.8 \mathrm{a}$ & $1.9 \mathrm{a}^{\mathrm{y}}$ & $2.0 \mathrm{~d}$ & $0.4 \mathrm{~d}$ & $2.4 \mathrm{~d}$ & $22 \mathrm{~b}$ \\
\hline
\end{tabular}

${ }^{2}$ Different letters indicate a significant difference within columns at $P=0.05$ according to Fisher's protected least significant difference test.

${ }^{y}$ Significant difference at $0.05 P$ level.

bensulide did not cause injury, reductions in turf quality, or reduce root length or root mass (data not shown) but cultivars varied significantly. 'Tifdwarf', 'FloraDwarf', and 'MiniVerde' had similar total root mass after 8 weeks, but compared with these cultivars, 'Champion' and 'TifEagle' had 36\% and $88 \%$ less total root mass, respectively (Table 5). In field experiments, White (1998) noted 'TifEagle' had $63 \%$ and $56 \%$ less root mass compared with 'Tifdwarf' and 'Champion' bermudagrass, respectively, 4 months after establishment. 'TifEagle' bermudagrass was the only cultivar to have reduced root length and root mass from other cultivars. Herbicide treatment had no effect on clipping yield 4 WAT (data not shown), whereas only treated 'TifEagle' and 'FloraDwarf' bermudagrass had $32 \%$ and $25 \%$ reduced clipping yield 8 WAT from that nontreated, respectively.

\section{Conclusions}

In field experiments, 'TifEagle' bermudagrass showed the most sensitivity to mitotic inhibitors, bensulide, dithiopyr, napropamide, and pendimethalin. Regression analysis suggests significantly lower rates of these herbicides may have an acceptable margin of safety on dwarf bermudagrass, but further research should investigate efficacy for weed control and turf safety. Oxadiazon plus bensulide caused acceptable levels of root growth reductions $(15 \%)$ in the field and did not reduce root mass of five dwarf bermudagrass cultivars in greenhouse experiments. Overall, oxadiazon or oxadiazon plus bensulide will likely be the only suitable preemergence herbicides for dwarf-type bermudagrass golf greens, whereas mitotic inhibitors used for higher-mowed bermudagrass cultivars and creeping bentgrass golf greens appear injurious.

\section{Literature Cited}

Bayer Environmental Sciences. 1998. Ronstar G specimen label. Montvale, N.J.

Beard, J.B. 1973. Turfgrass science and culture. Prentice-Hall, Inc., Englewood Cliffs, N.J.

Bingham, S.W. 1967. Influence of herbicides on root development of bermudagrass. Weeds 15:363-365.

Burton, G.W. 1991. A history of turf research at Tifton. USGA Green Section Record 29: $12-14$.
Bunnell, B.T., L.B. McCarty, J.E. Faust, W.C. Bridges, and N.H. Rajapakse. 2005. Quantifying a daily light integral requirement of a 'TifEagle' bermudagrass golf green. Crop Sci. 45:569-574.

Bunnell, B.T., L.B. McCarty, D.B. Lowe, and J.K. Higingbottom. 2001. Kyllinga squamulata control in bermudagrass turf. Weed Tech. 15:310-314.

Callahan, L.M. 1976. Phytotoxicity of herbicides to a Tifgreen bermudagrass green. Weed Sci. 24:92-98.

Callahan, L.M. and J.W. High. 1990. Herbicide effects on bermudagrass lawn recovery and crabgrass control during spring root decline in the north-south transition zone. J. Amer. Soc. Hort. Sci. 115:597-601.

Capo-chichi, L.J.A., J.M. Goatley, Jr., W. Philley, J. Krans, D. Davis, A. Kato, and E. van Santen. 2005. Dinitroaniline-induced genetic changes in bermudagrass. Crop Sci. 45:1504-1510.

Dernoeden, P.H., N.E. Christains, J.M. Krouse, and R.G. Roe. 1993. Creeping bentgrass rooting as influenced by dithiopyr. Agron. J. 85:560-563.

Dernoeden, P.H., T.L. Watschke, and J.K. Mathias. 1984. Goosegrass (Eleusine indica) control in turf in the transition zone. Weed Sci. 32:4-7.

Dow AgroSciences LLC. 2003. Dimension EC product label. Indianapolis, Ind.

Engel, R.E. and L.M. Callahan. 1967. Merion Kentucky bluegrass response to soil residue of preemergence herbicides. Weeds 15 : $128-130$.

Engel, R.E. and R.D. Ilnicki. 1969. Turf weeds and their control, p. 240-282. In: A.A. Hanson and F.V. Juska (eds.). Agronomy Monograph No. 14. Turfgrass. American Society of Agronomy, Madison, Wis.

Fagerness, M.J., F.H. Yelverton, and R.J. Cooper. 2002. Bermudagrass [Cynodon dactylon (L.) Pers]. and zoysiagrass (Zoysia japonica) establishment after preemergence herbicide applications. Weed Technol. 16:597-602.

Ferrell, J.A., T.R. Murphy, and W.K. Vencill. 2003. Tolerance of winter-installed tall fescue (Festuca arundinacea) and hybrid bermudagrass (Cynodon transvaalensis $\times$ C. dactylon) sod to herbicides. Weed Technol. 17: 521-525.

Finney, S.B. 1991. Cellular responses of bentgrass and bermudagrass to selected preemergence herbicides. Weeds 15:128-130

Foy, J.H. 1991. Going for the gold with bermudagrass greens. USGA Green Section. 29:1-4.

Fry, J.D., P.H. Dernoeden, and J.J. Murray. 1986. Establishment and rooting of zoysiagrass (Zoysia japonica) as affected by preemergence herbicides. Weed Sci. 34:413-418.

Gowan Company. 2004. Devrinol product label. Trenton, N.J. p. 2.
Hanna, W.W. and J.L. Elsner. 1999. Registration of TifEagle bermudagrass. Crop Sci. 39:1258.

Hart, S.E., D.W. Lycan, and J.A. Murphy. 2004. Response of creeping bentgrass (Agrostis palustris Huds.) to fall applications of bensulide and dithiopyr. Weed Technol. 18:1072-1076.

Johnson, B.J. 1976a. Dates of herbicide application for summer weed control in turf. Weed Sci. 24:422-424.

Johnson, B.J. 1976b. Bermudagrass tolerance to consecutive butralin and oxadiazon treatments. Weed Sci. 24:302-305.

Johnson, B.J. 1979. Vertical mowing and herbicide treatments on thatch in bermudagrass (Cynodon dactylon) turf. Weed Sci. 27:14-17.

Johnson, B.J. 1980. Root growth of southern turf cultivars as affected by herbicides. Weed Sci. 28:526-528.

Johnson, B.J. 1985. Response of four bermudagrass (Cynodon dactylon) cultivars to dates of oxadiazon treatments. Weed Sci. 33:371-375.

Johnson, B.J. and R.E. Burns. 1985. Effect of soil $\mathrm{pH}$, fertility, and herbicides on weed control and quality of bermudagrass (Cynodon dactylon) turf. Weed Sci. 33:366-370.

Lesco, Inc. 2001. Pre-M 60 DG herbicide label. Strongsville, Ohio.

McCarty, L.B. and G.L. Miller. 2002. Managing bermudagrass turf: Selection, construction, cultural practices and pest management strategies. Sleeping Bear Press, Chelsea, Mich.

McCarty, L.B. and T. Murphy. 1994. Control of turfgrass weeds, p. 209-248. In: A.J. Turgeon (ed.). Turf weeds and their control. American Society of Agronomy, Madison, Wis.

McCullough, P.E., H. Liu, L.B. McCarty, T. Whitwell, and J.E. Toler. 2006. Bermudagrass putting green quality, growth, and nutrient partitioning influenced by nitrogen and trinexapacethyl. Crop Sci. 46:1515-1525.

P.B.I. Gordon Corp, 2004. Bensulide 4LF product label. Kansas City, Mo. p. 2.

Rao, V.S. 2000. Principles of weed science, 2nd Edition. Science Publishers, Inc., Enfield, N.H.

Ross, M.A. and C.A. Lembi. 1999. Applied weed science, 2nd Edition. Prentice Hall, Upper Saddle River, N.J.

SAS Institute. 1999. The SAS system for Windows. v. 8.2. SAS Inst., Cary, N.C.

Toler, J.E., L.B. McCarty, and J.K. Higingbottom. 2003. New options for annual bluegrass control in overseeded bermudagrass putting greens. HortScience. 38:1232-1234.

U.S. Golf Assoc. Green Section Staff. 1993. USGA recommendations for a method of putting green construction. The 1993 revision. USGA Green Section Record. 31:1-3.

Vaughn, K.C. and L.P. Lehnen. 1991. Mitotic disrupter herbicides. Weed Sci. 39:450-457.

Webster, T.M., C.W. Bednarz, and W.H. Hanna. 2003. Sensitivity of triploid hybrid bermudagrass cultivars and common bermudagrass to postemergence herbicides. Weed Technol. 17:509-515.

White, R.H. 1998. Performance and management of new dwarf bermudagrasses. 1998 SemiAnnual Research Progress Report. Texas Agriculture Experiment Station. Texas A \& M University. p. 12.

White, R.H., T.C. Hale, D.R. Chalmers, M.H. Hall, J.C. Thomas, and W.G. Menn. 2004. Cultural management of selected ultradwarf bermudagrass cultivars. Online. Crop Management. 